\title{
Global and Regional IUCN Red List Assessments: 9
}

\author{
Simone Orsenigo', Liliana Bernardo², Salvatore Cambria ${ }^{3}$, Domenico Gargano², \\ Valentina L.A. Laface ${ }^{4}$, Carmelo M. Musarella ${ }^{4}$, Nicodemo G. Passalacqua ${ }^{5}$, \\ Giovanni Spampinato ${ }^{4}$, Gianmarco Tavilla ${ }^{3}$, Giuseppe Fenu ${ }^{6}$
}

I Department of Earth and Environmental Sciences, University of Pavia, Via S. Epifanio 14, 27100, Pavia, Italy 2 Department of Biology, Ecology, and Earth Sciences, University of Calabria, Via P. Bucci, Rende, 87036, Italy 3 Department of Biological, Geological and Environmental Sciences, University of Catania, Via Antonio Longo 19, 95125, Catania, Italy 4 Department of AGRARIA, "Mediterranea" University of Reggio Calabria, Località Feo di Vito, 89122, Reggio Calabria, Italy 5 Museo di Storia Naturale della Calabria ed Orto Botanico dell'Università della Calabria, Via N. Savinio, Rende, 87036, Italy 6 Department of Life and Environmental Sciences, University of Cagliari, Viale S. Ignazio da Laconi 13, 09123, Cagliari, Italy

Corresponding author: Simone Orsenigo (simone.orsenigo@unipv.it)

Academic editor: Lorenzo Peruzzi | Received 8 June 2020 | Accepted 6 July 2020 | Published 13 July 2020

Citation: Orsenigo S, Bernardo L, Cambria S, Gargano D, Laface VLA, Musarella CM, Passalacqua NG, Spampinato G, Tavilla G, Fenu G (2020) Global and Regional IUCN Red List Assessments: 9. Italian Botanist 9: 111-123. https:// doi.org/10.3897/italianbotanist.9.55223

\begin{abstract}
In this contribution, the conservation status assessment of three vascular plants according to IUCN categories and criteria are presented. It includes the assessment of Soldanella calabrella Kress at global level, and the regional assessment of Luzula pindica (Hausskn.) Chrtek \& Kř́sa and Romulea variicolor Mifsud (Italy).
\end{abstract}

\section{Keywords}

conservation, extinction risk, IUCN protocol, threats

\section{How to contribute}

The text of the global and regional assessments should be submitted electronically to Simone Orsenigo (simone.orsenigo@unipv.it) or to Giuseppe Fenu (gfenu@unica.it); the text, up to 8000 characters in length (spaces included), must include a distribution map and a picture of the assessed species. 


\section{Red List assessments}

Luzula pindica (Hausskn.) Chrtek \& Kř́sa

Regional assessment (Italy)

Taxonomy and nomenclature

Order: Poales Family: Juncaceae

Luzula pindica (Hausskn.) Chrtek \& Kř́ísa Webbia 19: 6 (1964) 三Luzula spicata (L.)

DC. var. pindica Hausskn., Mitth. Thüring. Bot. Vereins, n.f., 13-14: 33 (1899)

Common name: Erba lucciola del M. Pindo (It), Pindus woodrush (En).

Geographic distribution range: The main range of Luzula pindica (Fig. 1) includes the mountain areas of the Balkan region, but this species reaches its western distribution limit in southern Italy (Chrtek and Kř́sa 1980). In the context of the species' range, the Italian populations define a striking disjunction. Accordingly, this plant represents one of the most remarkable examples of Amphi-Adriatic taxa within the Italian vascular flora. As found for other taxa with a similar geographical pattern (e.g., Gentianella crispata (Vis.) Holub: Gargano et al. 2009), in Italy L. pindica is confined to a small area at the southern extreme of the Apennine chain. Indeed, some historical records (from the beginning of the $20^{\text {th }}$ century or earlier) reporting the presence of this species on Mt. Volturino and the Sila mountains (Chrte and Kř́sa 1964) were not later confirmed. Therefore, the ascertained Italian range of $L$. pindica currently includes just a few localities in a restricted area of the massif of Mt. Pollino (Fig. 2) that falls within the Administrative Regions of Basilicata and Calabria (Bernardo et al. 2014).

Distribution: Countries of occurrence: Albania, Bulgaria, Greece, Italy, and North Macedonia.

Biology: Plant growth form: perennial (caespitose hemicryptophyte).

Flowering time: From June to July.

Reproduction: Luzula is mostly wind-pollinated, while seed dispersal generally relies on myrmecochory (e.g., Oostermeijer 1989).

Habitat and ecology: Luzula pindica grows on limestone, within high-mountain grasslands established close or above the treeline. Accordingly, this species is associated to the Ranunculo-Nardion vegetation (Tomaselli et al. 2003), which includes the mesophilous grasslands and the fragments of snowbed vegetation of the S-Apennines (Gargano et al. 2010).

Population information: Since 2016, this species is included in a monitoring program focused on the oro-Mediterranean herbaceous communities of the Pollino National Park. The demographical data obtained from permanent sampling areas indicate that flowering rates of $L$. pindica range from 19.7 to 2.7 flowering stalks $/ \mathrm{m}^{2}$. To date, it is difficult to deduce a clear demographic trend. However, data related to different periods of the blooming seasons show that the species is subjected to intense grazing; indeed, during the four years of observation, the percent of grazed flowering stalks ranged from 87.5 to $100 \%$. 


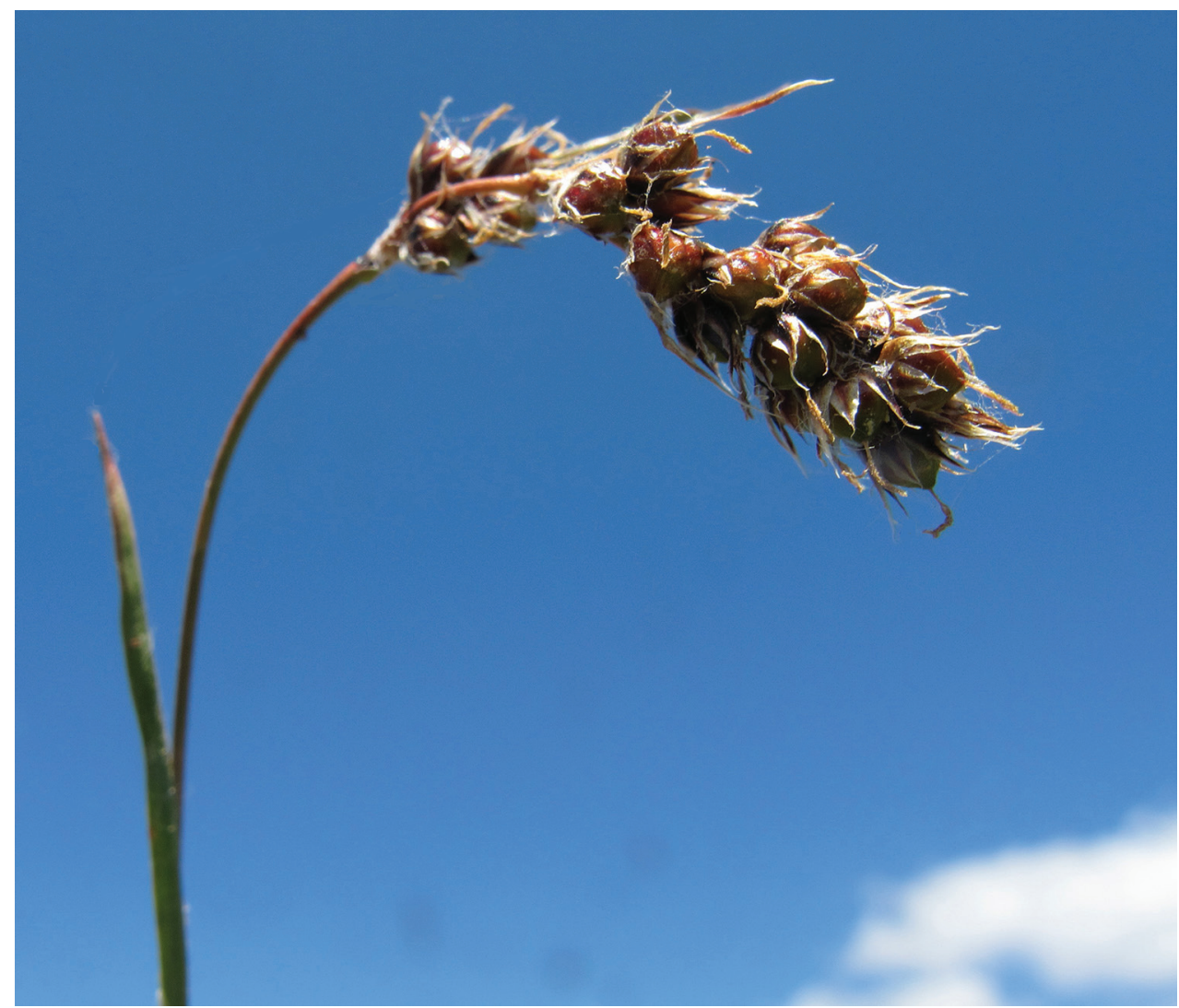

Figure I. Luzula pindica at Piani di Pollino (Terranova di Pollino, Potenza, Basilicata), a locality included in the Pollino National Park. Photograph by Liliana Bernardo.

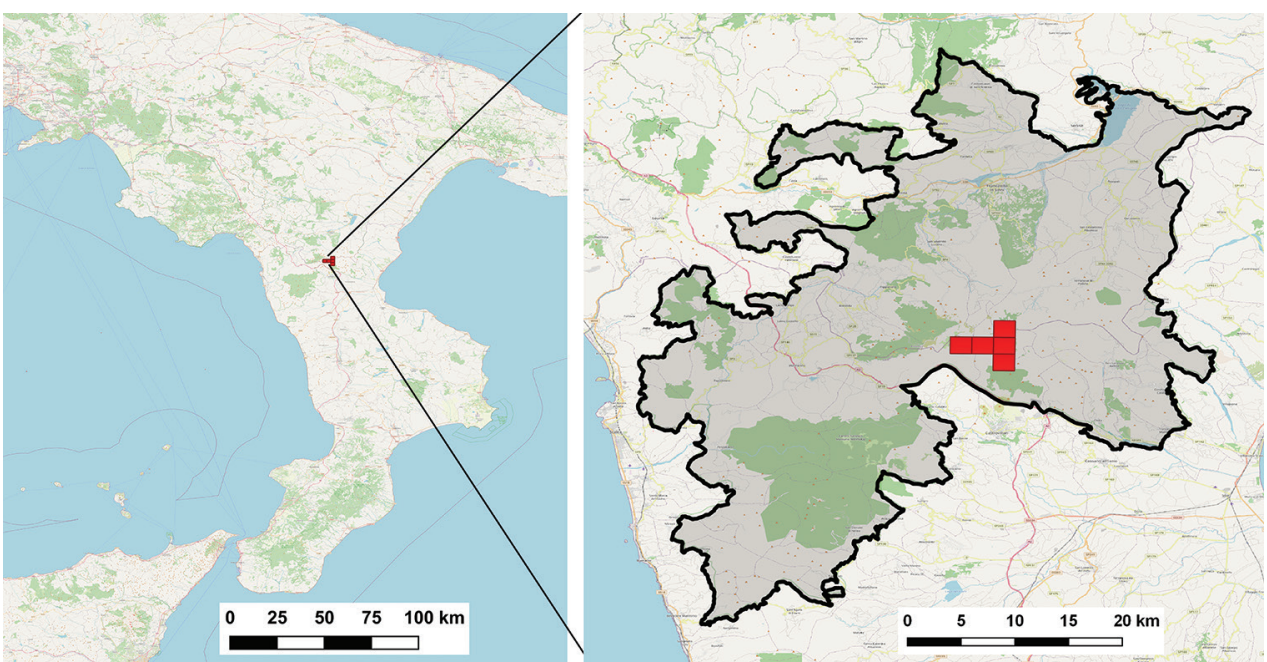

Figure 2. Left side: area of occupancy of Luzula pindica in the southern Italian peninsula; right side: location of the AOO cells with respect to the boundaries of the Pollino National Park (light shaded area). 
Threats: 2.3. Livestock and farming and ranching: the grasslands hosting this species are subjected to over-grazing pressure during the flowering season. Trampling due to nomadic domestic animals reduces the soil quality by promoting erosion and nitrification; the excessive grazing rate represents a severe limitation to sexual recruitment in all known populations of $L$. pindica.

\section{CRITERIA APPLIED:}

Criterion B: EOO: $20 \mathrm{~km}^{2}$.

AOO: $20 \mathrm{~km}^{2}$ calculated with a $2 \times 2 \mathrm{~km}$ fixed cell grid (Gargano 2011).

a) Number of locations: all the populations occur in a restricted area; the growth contexts are highly homogeneous and show a comparable regime of over-grazing. For these reasons, $L$. pindica is believed to occupy a unique location in Italy.

b) Due to over-grazing, the habitat quality (iii) is declining in many sites, as well as the number of mature individuals (v). Since the plant was no longer observed in some historical sites of its regional range, a reduction of EOO and AOO may have also affected the species in Italy, but this is difficult to prove and quantify.

\section{Red List category and Criteria (Regional Assessment)}

\section{\begin{tabular}{|l|l|l}
\hline CR & Critically Endangered & B1ab(iii,v)
\end{tabular}}

Rationale for the assessment: In Italy, $L$. pindica is confined to a few sites within a small mountain area of the peninsula. The current regional distribution accounts for an EOO and AOO of only $20 \mathrm{~km}^{2}$. This species is threatened by excessive grazing pressure, which can alter the quality of the habitat and reduce the rate of reproductive success. Due to the contiguity of the inhabited sites, and their homogeneous sensitivity to the prevalent threat, $L$. pindica occurs in a single location. The absence of recent records for some historical sites suggests a historical reduction of the regional range. Currently, due to the marked geographical rarity, the occurrence in a single location, and the effect of over-grazing on habitat quality and on the population's reproductive processes, this taxon qualifies as Critically Endangered (CR) at the regional level. Because geographical isolation makes any contribution of the populations occurring in Eastern Europe to the conservation status of the Italian ones unlikely, there is no reason for up- or down-grading the risk category resulting from this assessment procedure.

Previous assessment: This taxon is Not Evaluated (NE) at the global level (IUCN 2020), while it is as Endangered (EN) in the Red List of the Italian vascular flora (Orsenigo et al. 2020).

Conservation actions: All known Italian populations of $L$. pindica occur within the Pollino National Park.

Conservation actions needed: It is necessary to improve the site management in order to reduce the impact of grazing on this species during the flowering period. This would allow to enhance the quality of the growth context and to improve the rates of 
sexual recruitment. Seed banking would be also an effective way to preserve the species' genetic resources and support future reinforcement trials.

Domenico Gargano, Nicodemo G. Passalacqua, Liliana Bernardo

\section{Romulea variicolor Mifsud}

Regional assessment (Italy)

Taxonomy and nomenclature

Order: Asparagales Family: Iridaceae

Romulea variicolor Mifsud, Webbia 70: 257 (2015) - Romulea melitensis auct. Fl. Ital. et Malta

Common name: Zafferanetto maltese, Romulea maltese (It); Maltese Sand Crocus (En).

Geographic distribution range: Romulea variicolor (Fig. 3) is native to Malta and Sicily (Italy). Previously, it was reported by some authors (Haslam et al. 1977; Frignani and Iiriti 2001) as Romulea melitensis Béguinot. However, Mifsud (2015) suggested that this taxonomic treatment should be considered as ambiguous, describing the new name $R$. variicolor. This species was reported for the first time in Sicily by Brullo et al. (2009) and later confirmed by Mifsud (2015). Its Italian distribution is restricted to a small coastal stretch between Cava d'Aliga and Marina di Modica (Ragusa, Sicily) (Fig. 4).

Distribution: Countries of occurrence: Italy (Sicily), Malta.

Biology: Plant growth form: perennial (bulbous geophyte).

Flowering and fruiting time: Flowering from February to March and fruiting from March to April.

Reproduction: No detailed information is available on the pollination system and seed dispersal mechanism.

Habitat and ecology: Romulea variicolor grows on sandstones and Miocene limestones (0-100 m a.s.l.), within the lower upper semiarid thermomediterranean bioclimatic belt (Bazan et al. 2015). From a phytosociological point of view, in the Maltese Islands this plant was considered by Brullo et al. (2020) as a differential species of the Romuleo melitensis-Ranunculetum bullati, an association framed within the Leontondonto tuberosi-Bellidion sylvestris Biondi, Filigheddu and Farris 2001 (Lygeo spartiStipetea tenacissimae Rivas-Martinez 1978). In Sicily, it shows similar ecological requirements, colonizing small flat surfaces among the low shrubs of coastal garrigues or halophilous communities with Limonium hyblaeum Brullo (Brullo et al. 2009). From a biogeographical perspective, the population of Romulea variicolor falls within the Camarino-Pachinense district (Brullo et al. 1995).

Population information: In Sicily, $R$. variicolor is represented by few groups of individuals circumscribed to the south-eastern coast of the island, in the province of Ra- 


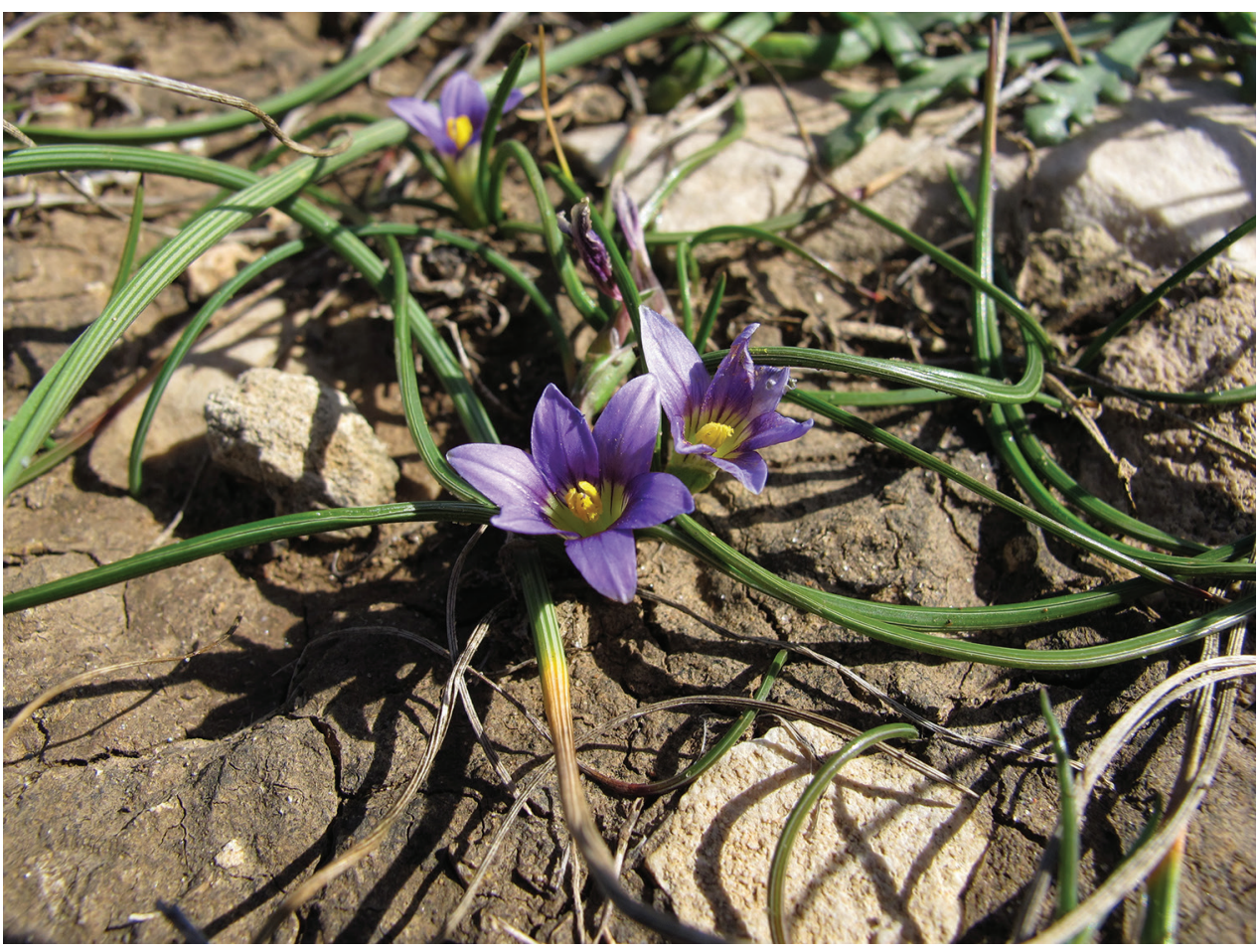

Figure 3. Romulea variicolor in the rocky coast near Sampieri (Ragusa, Sicily). Photograph by S. Cambria.

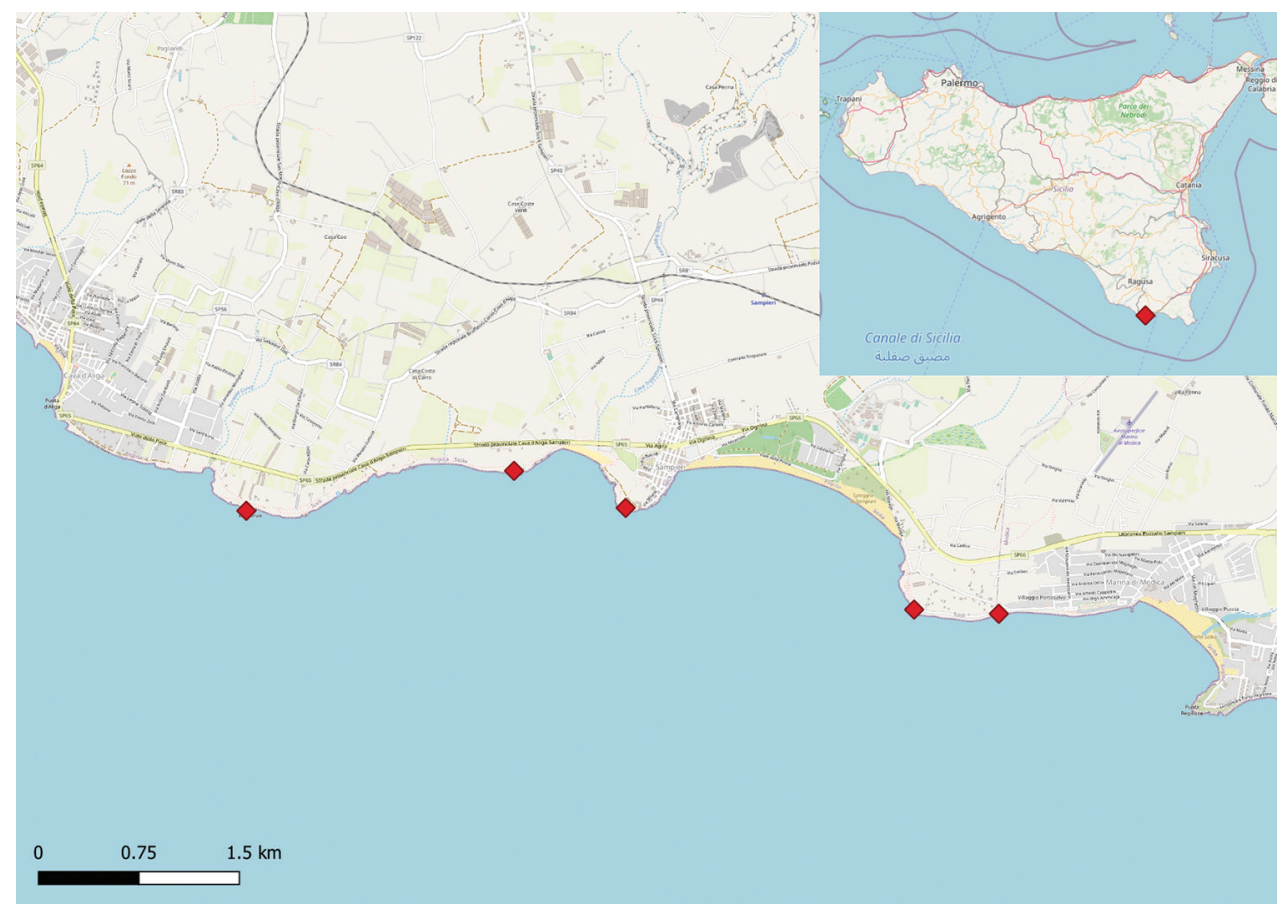

Figure 4. Geographical range and distribution map of Romulea variicolor Mifsud in Sicily. 
gusa. This species shows an extremely scattered distribution with few isolated patches, where it is sometimes locally abundant for an estimated total number of a few hundred individuals. Mifsud (2018) reported a stable population trend, while direct observations of the Sicilian population indicate a slight regression and thus its progressive decline.

Threats: 1.1 Housing \& Urban Areas: the modifications of urban areas impact on the habitat of this species.

8.1 Invasive Non-Native/Alien Species/Diseases: the species' range can be reduced by invasive alien plants, such as Carpobrotus edulis (L.) N.E.Br.

1.3 Tourism \& Recreation Areas: the coastal area is strongly subject to tourist activities during the summer season.

7.3. Other ecosystems modifications: many of the stands are subject to coastal erosion.

\section{CRITERIA APPLIED}

Criterion B: AOO: $16 \mathrm{~km}^{2}$ calculated with GeoCAT (Geospatial Conservation Assessment Tool) software (Bachman et al. 2011).

a) Number of locations: we identified five locations based on urbanization that represents the main threat affecting the species.

b) Decline observed in (iii) area, extent and/or quality of habitat; (v) number of mature individuals.

\section{Red List category and Criteria (Global Assessment)}

\begin{tabular}{|l|l|l}
\hline EN & Endangered & B2ab(iii,v) \\
\hline
\end{tabular}

Rationale for the assessment: Romulea variicolor is a geophyte endemic of the Maltese islands and south-eastern Sicily. In Italy, this species shows a localized distribution in Sicily, being limited to a small coastal area strongly affected mainly by urbanization, tourism and other risk factors. Populations are represented by scattered groups with few individuals, clearly subject to a decline, particularly for locations closest to urban centers and tourist sites. The regional distribution range consists in an $\mathrm{AOO}$ of $16 \mathrm{~km}^{2}$. Considering the exiguous number of stands and the presence of several threats, this taxon can be classified as Endangered (EN).

Previous assessment: Romulea variicolor was evaluated as Least Concern (LC) at a global level (Mifsud 2018) and, more recently, as Data Deficient (DD) in Italy (Orsenigo et al. 2020).

Conservation actions: Romulea variicolor is unprotected by international, national and regional specific laws. The Sicilian population partly falls within the SAC ITA080008 'Contrada Religione'. Moreover, the area at issue has been identified as an Important Plant Area (IPA), essential for the conservation of plant biodiversity, indicated as "Costa di Sampieri (SIC 16)".

Conservation actions needed: Research activities (e.g., demographic, eco-physiological, etc.) are advisable and an improved quality of the habitat is necessary for in situ conservation. 


\section{Soldanella calabrella Kress}

Global Assessment

\section{Taxonomy and nomenclature}

Order: Ericales Family: Primulaceae

Soldanella calabrella Kress, Primulac.-Stud. 8: 24 (1988) - Soldanella hungarica auct. Fl. Ital.

Common name: Soldanella calabrese (It), Calabrian Soldanella (En).

Geographic distribution range: Soldanella calabrella Kress (Fig. 5) is endemic to Calabria (Fig. 6), and its distribution consists of two disjunct populations in Sila and Aspromonte. Cristofolini and Pignatti (1962) attributed the Calabrian populations to S. hungarica Simonk., underlining their significant disjunction concerning the main distribution area. Later, Pignatti (1982) reported for Sila and Apromonte the presence of $S$. hungarica, stating in a note that the Calabrian Soldanella could represent an as yet unreported species. Finally, Kress (1988) classified the Calabrian plants as Soldanella calabrella. Zhang et al. (2001), in their review of the genus Soldanella L., confirmed the autonomy of this species.

Distribution: Country of occurrence: Italy.

Biology: Plant growth form: Perennial (hemicryptophyte)

Flowering and fruiting time: Flowering from May to June and fruiting from June to August.

Reproduction: Soldanella calabrella is an insect-pollinated species. Dispersal mechanisms are barochory and hydrochory (for long-distance dissemination). No information on seed germination is available.

Habitat and ecology: Soldanella calabrella grows near springs or on shady and damp walls subject to dripping along the mountain streams with permanent, weakly flowing and well-oxygenated waters. This habitat is located within deciduous mesophilous forests of Fagus sylvatica L. often associated with Abies alba Mill. on acid crystalline rocks of the mountain belt. The altitude range falls between 1,200 and 1,900 m a.s.l., in upper supratemperate or lower orotemperate bioclimate (Brullo et al. 2001). Soldanella calabrella is a characteristic species of the Adenostylo-Soldanelletum calabrellae Signorello 1986 corr. Brullo, Scelsi and Spampinato 2001, an association of the Caricion remotae Kästner 1941 alliance (Brullo et al. 2001).

Population information: this species shows a highly fragmented and disjunct distribution, with two macro distribution areas, the Sila mountains (where it is further fragmented into two sub-areas: Sila Grande and Sila Piccola) and the Aspromonte massif. A total of 25 localities was confirmed in 2019 (10 in Aspromonte, 7 in Sila Grande, and 8 in Sila Piccola). Four of the past sites of occurrence documented in the literature (Brullo et al. 2001, Spampinato et al. 2008) were not confirmed by recent surveys carried out in 2019. Due to ecological factors and habitat threats, populations range from several hundred up to a few individuals limited to very small areas. 


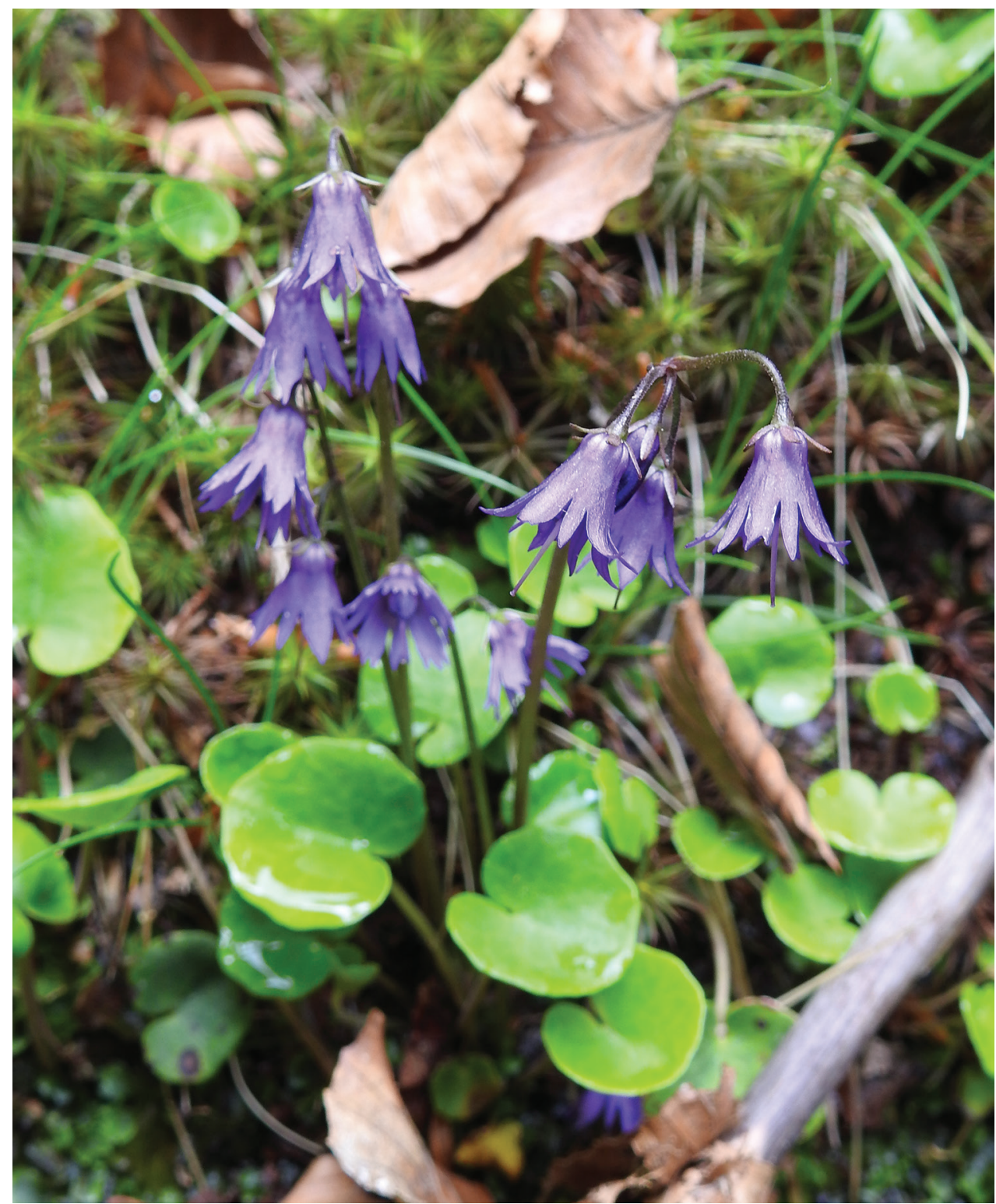

Figure 5. Soldanella calabrella Kress, at Materazzelli (Cosoleto, Reggio Calabria). Photograph by V.L.A. Laface.

Threats: 2.3.1 Nomadic grazing: many grazing animals, in particular, cows (Bos taurus) and wild boar (Sus scrofa), drink in the streams and springs where the species grows, damaging the habitat.

5.3 Logging \& wood harvesting: the localities at lower altitudes are located in areas subject to forestry uses that severely modify the habitat. The threat is still present, therefore a further drop in the number of individuals and habitat quality can be expected. 


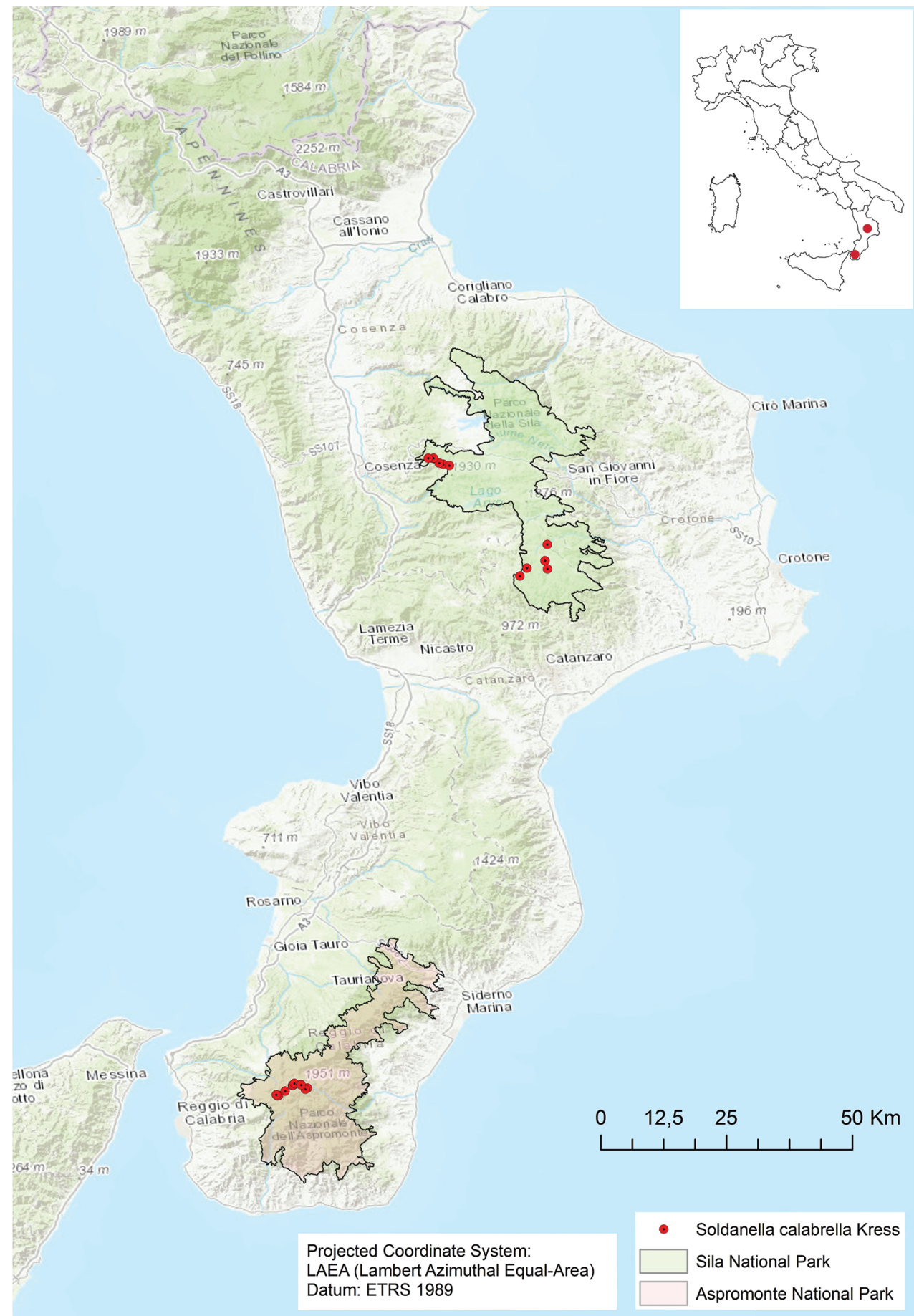

Figure 6. Geographical range and distribution map of Soldanella calabrella Kress. 
11.1 Habitat shifting \& alteration: field surveys show that the lower-altitude stations are the most threatened by the natural evolution of habitats due to climate change. This species is restricted to the microclimate occurring in streams and springs of the mountain belt.

11.2 Drought: the survival of $S$. calabrella is tied to peculiar wet habitats; drought, therefore, causes the rapid disappearance of the species.

11.4 Storms and floods: they cause landslides, collapses, erosion or sediment deposition, causing the loss of suitable species habitat.

\section{CRITERIA APPLIED:}

Criterion B: EOO: 2,203 $\mathrm{km}^{2}$ calculated with minimum convex hull polygon using ArcMap10.4.

AOO: $44 \mathrm{~km}^{2}$ calculated with $2 \times 2 \mathrm{~km}$ cell fixed grid in the ArcMap10.4. a) number of locations $>5$

b) Habitat extent and quality (iii) are declining, as well as the number of mature individuals (v). A reduction of AOO (ii) is likely to have affected the species.

Criterion A2: reduction in the estimated population as a function of an $\mathrm{AOO}$ reduction $>30 \%$ in 10 years, which continues today due to declining habitat quality and habitat destruction.

c) documented decline in $\mathrm{AOO}$ and habitat quality, according to threats 11.1, 11.2,11.4, and 2.3.1

\section{Red List category and Criteria (Global Assessment)}

\begin{tabular}{|l|l|l}
\hline VU & Vulnerable & A2c + B1ab(ii,iii,v) + 2ab(ii,iii.v)
\end{tabular}

Rationale for the assessment: The populations are scattered as a consequence of its peculiar habitat: shady and damp walls subject to dripping near springs or along the perennial streams of the mountain belt. A decline in population size is documented by a continuous and significant reduction in $\mathrm{AOO}$. The AOO decreased from $64 \mathrm{~km}^{2}$ to $44 \mathrm{~km}^{2}$ in the last 10 years, due to the fore-mentioned threats that affect the extent and quality of the habitat. The individuals located at lower altitudes are the most threatened by the anthropic impact (logging, water abstraction, and grazing) and by climate change, which have already led to the extinction of some populations in the last decades. Based on new data that document a decline in AOO, quality of habitat, and number of mature individuals, S. calabrella can be considered "Vulnerable (VU)" at global level according to IUCN criteria (IUCN 2012).

Previous assessment: the species was previously assessed as "Endagered (EN)" at global level (Orsenigo et al. 2018).

Conservation actions: Soldanella calabrella is unprotected by regional, national or international laws. The current localities of this species fall within the Aspromonte and Sila National Park. 
Conservation actions needed: Monitoring and research activities are needed to evaluate population dynamics and trends. Specific control and protection measures must be taken to preserve the habitat and the species.

Valentina Lucia Astrid Laface, Carmelo Maria Musarella, Giovanni Spampinato

\section{References}

Bachman S, Moat J, Hill AW, Torre J de la, Scott B (2011) Supporting Red List threat assessments with GeoCAT: geospatial conservation assessment tool. In: Smith V, Penev L (Eds) E-Infrastructures for data publishing in biodiversity science. ZooKeys 150: 117-126. https://doi.org/10.3897/zookeys.150.2109 [Version BETA]

Bazan G, Marino P, Guarino R, Domina G, Schicchi S (2015) Bioclimatology and Vegetation Series in Sicily: A geostatistical approach. Annales Botanici Fennici 52(1-2): 1-18. https:// doi.org/10.5735/085.052.0202

Bernardo L, Passalacqua NG, Peruzzi L (2014) Luzula pindica (Hausskn.) Chrtek \& Kř́sa (Juncaceae). In: Barberis G, Nepi C, Peruzzi L, Peccenini S (Eds) Notulae alla checklist della flora vascolare italiana 18 (2071-2099). Informatore Botanico Italiano 46(2): 1-276.

Brullo S, Brullo C, Cambria S, Giusso del Galdo G (2020) The Vegetation of Maltese Islands. Geobotany Studies, Springer. https://doi.org/10.1007/978-3-030-34525-9

Brullo C, Brullo S, Giusso del Galdo G (2009) Notes on the occurrence of Romulea melitensis (Iridaceae) in Sicily - a critical species of the Mediterranean flora. In: Peccenini S, Domina G (Eds) Gruppi Critici della Flora d'Italia, Comunicazioni. 30-31 ottobre 2009, Roma.

Brullo S, Minissale P, Spampinato G (1995) Considerazioni fitogeografiche sulla flora della Sicilia. Ecolologia Mediterranea 21(1-2): 99-117. https://doi.org/10.3406/ecmed.1995.1759

Brullo S, Scelsi F, Spampinato G (2001) La vegetazione dell'Aspromonte. Studio fitosociologico. Laruffa Editore, Reggio Calabria, 368 pp.

Chrtek J, Křísa B (1964) On the problem of the species Luzula spicata (L.) DC. in Italy. Webbia 19: 1-10. https://doi.org/10.1080/00837792.1964.10669801

Chrtek J, Křísa B (1980) Luzula DC. In: Tutin TG, Heywood VH, Burges NA, Moore DM, Valentine DH, Walters SM, Webb DA (Eds) Flora Europaea 5, Cambridge University Press, Cambridge.

Cristofolini G, Pignatti S (1962) Revisione delle forme Italiane del genere Soldanella L. Webbia 16: 443-475. https://doi.org/10.1080/00837792.1962.10669727

Frignani F, Iiriti G (2001) The genus Romulea in Italy: taxonomy, ecology and intraspecific variation in relation to the flora of Western Mediterranean islands. Fitosociologia 48(2) suppl. 1: 13-20.

Gargano D (2011) Toward a New List of the Italian Flora: a standard grid for estimating the area of occupancy (AOO). Informatore Botanico Italiano 43(2): 455-458.

Gargano D, Bellusci F, Pellegrino G, Palermo AM, Bernardo L, Musacchio A (2009) The conservation perspectives and value of small and isolated plant populations: preliminary clues 
for Gentianella crispata (Gentianaceae) at the western border of its range. Annales Botanici Fennici 46: 115-124. https://doi.org/10.5735/085.046.0206

Gargano D, Vecchio G, Bernardo L (2010) Plant soils relationships in fragments of Mediterranean snow-beds: ecological and conservation implications. Plant Ecology 207: 175-189. https://doi.org/10.1007/s11258-009-9663-7

Haslam SM, Sell PD, Wolseley PA (1977) A Flora of the Maltese Islands. Malta University Press, Msida.

IUCN (2012) IUCN Red List Categories and Criteria: Version 3.1. Second Edition. IUCN Species Survival Commission. IUCN, Gland, Switzerland and Cambridge, 32pp.

IUCN (2020) The IUCN Red List of Threatened Species vers. 2020-1. http://www.iucnredlist.org Kress A (1988) Primulaceen-Studien 8: Der Formenkreis um Soldanella chrysosticta. Gröbenzell bei München.

Mifsud S (2015) A review of Romulea Maratti (Iridaceae) in the Maltese Islands. Webbia 70(2): 247-287. https://doi.org/10.1080/00837792.2015.1071910

Mifsud S (2018) Romulea variicolor. The IUCN Red List of Threatened Species 2018: e.T87637491A87637638. https://doi.org/10.2305/IUCN.UK.2018-1.RLTS. T87637491A87637638.en

Oostermeijer JGB (1989) Myrmecochory in Polygala vulgaris L., Luzula campestris (L.) DC. and Viola curtisii Forster in a Dutch dune area. Oecologia 78: 302-311. https://doi. org/10.1007/BF00379102

Orsenigo S, Fenu G, Gargano D, Montagnani C, Abeli T, Alessandrini A, Bacchetta G, Bartolucci F, Carta A, Castello M, Cogoni D, Conti F, Domina G, Foggi B, Gennai M, Gigante D, Iberite M, Peruzzi L, Pinna MS, Prosser F, Santangelo A, Selvaggi A, Stinca A, Villani M, Wagensommer RP, Tartaglini N, Duprè E, Blasi C, Rossi G (2020) Red List of threatened vascular plants in Italy. Plant Biosystems. https://doi.org/10.1080/11263504. 2020.1739165

Orsenigo S, Montagnani C, Fenu G, Gargano D, Peruzzi L, Abeli T, Alessandrini A, Bacchetta G, Bartolucci F, Bovio M, Brullo C, Brullo S, Carta A, Castello M, Cogoni D, Conti F, Domina G, Foggi B, Gennai M, Gigante D, Iberite M, Lasen C, Magrini S, PerrinoEV, Prosser F, Santangelo A, Selvaggi A, Stinca A, Vagge I, Villani M, Wagensommer RP, Wilhalm T, Tartaglini N, Duprè E, Blasi C, Rossi G (2018) Red Listing plants under full national responsibility: Extinction risk and threats in the vascular flora endemic to Italy. Biological Conservation 224: 213-222. https://doi.org/10.1016/j.biocon.2018.05.030

Pignatti S (1982) Flora d'Italia 2: 285-286. Edagricole, Bologna.

Spampinato G, Cameriere P, Crisafulli A, Caridi D (2008) Carta della biodiversità vegetale del Parco Nazionale dell'Aspromonte. Quaderni di Botanica Ambientale e Applicata 19: 3-36.

Tomaselli M, Bernardo L, Passalacqua NG (2003) The vegetation of the Ranunculo-Nardion in the Southern Apennines (S-Italy). Phyton (Horn) 43: 39-57.

Zhang LB, Comes HP, Kadereit JW (2001) Phylogeny and Quaternary history of the European montane/alpine endemic Soldanella (Primulaceae) based on ITS and AFLP variation. American Journal of Botany 88: 2331-2345. https://doi.org/10.2307/3558393 